\title{
A Biochemichal and Ultrastructural Study on the Effect of Toluene on the Pars Distalis of Anterior Pituitary Glands of Adult Male Albino Rats
}

Original Article

\author{
Rasha R. Salem and Melad N. B. kelada
}

Department of Anatomy, Faculty of Medicine, Alexandria University, Egypt

\begin{abstract}
Background: Toluene is an environmental chemical pollutant and widely used as organic solvent and in production of many industrial products. It has systemic toxic effects on many organs as liver, kidney and the central nervous system and cause immune dysfunction. It can affect nerve myelination and cross the blood-brain barrier. Little is known about the exact effect of toluene exposure on the cells of anterior pituitary and no adequate studies were found about the effect of toluene on the morphological and histological structure of the pituitary cells.

Aim: To assess the ultra structural of the pars distalis after toluene exposure. And to correlate any biochemical changes with the histological alteration as a trial to know the possible mechanism behind these changes.

Materials and Methods: 20 adult male albino rats were divided into control group consisted of 10 rats and toluene exposed group 10 rats were exposed once a day to vapors of toluene $(1000 \mathrm{ppm})$ for 15 minutes for 45 days. Blood samples were taken from the heart chambers of for assessment of the thyroid stimulating hormone (TSH), follicle stimulating hormone (FSH), luteinizing hormone (LH), adrencorticotrophic hormone (ACTH), growth hormone (GH) and prolactin. The anterior lobes of pituitary glands were immediately dissected out. Each specimen was separated into two parts; one processed and stained with hematoxylin \& eosin and the other part was examined by electron microscope.

Results: Biochemical: in the toluene-exposed group there was significant reduction in plasma level of GH, TSH, FSH and LH hormones and non-significant reduction in ACTH prolactin.

Microscopic: the exposed group cells show complete loss of normal architecture in many areas and had vacuolated cytoplasm, shrunken asymmetrical nucleus with more thickened chromatin and few secretory granules.

Conclusion: The toluene exposure induced morphological changes in most of cells of pars distalis and their secreted hormones.
\end{abstract}

Received: 27 December 2019, Accepted: 02 February 2020

Key Words: Anterior pituitary, brain effects of toluene, occupational hazards of toluene, pars distalis, toluene exposure.

Corresponding Author: Melad N. B. kelada, MD, Department of Anatomy, Faculty of Medicine, Alexandira Univirsty, Egypt, Tel.: +20 1226636044, E-mail: meladkelada@ymail.com

ISSN: $1110-0559$, Vol. 43, No.3

\section{INTRODUCTION}

Toluene (toluol, methylbenzene, phenylmethane) is one of widely used organic solvent in many industrial processes and commerce. It is an aromatic hydrocarbon, lighter than water in its liquid form, but three times heavier than air as a vapor. Also, it is one of the environmental chemical pollutants that are colorless, sweet-smelling liquids, evaporate easily and belong to volatile (becomes vapor at room temperature) organic compounds ${ }^{[1,2]}$.

Misuse of these volatile organic compounds is a major problem among people especially kids and young age. It also represents a common cause of occupational and nonoccupational diseases ${ }^{[3]}$. Occupational exposure to toluene in workplaces such as factories, workshops, refineries or during washing and polishing of cars usually occurs several hours a day, five-six days a week. This lead to acute health symptoms in the workers ${ }^{[1,4]}$.

Moreover, toluene is a widely used to produce an array of polyurethane-containing products, including adhesives, sealants, paints, paint thinners, fingernail polish, lacquers, adhesives, flexible and rigid foams, rubber, textiles and electronic machinery. It is also produced in the process of making coke from coal and making gasoline and other fuels and in some printing and leather tanning processes ${ }^{[5]}$.

It is used in the production of benzene, nylon, plastics, and polyurethane and the synthesis of trinitrotoluene, benzoic acid, benzoyl chloride, and toluene diisocyanate. It evaporates rapidly from these materials and becomes mixed with the air. As, the world market for polyurethane products has increased nowadays, many epidemiologic and clinical evidence for the role of toluene diisocyanates and polyurethanes in the genesis of non-occupational disease have also been reported ${ }^{[5]}$.

Toluene is produced by the addition of a methyl group to the benzene ring, this structure makes ithas high fats affinity, more soluble in lipids and rapidlyevaporates ${ }^{[6]}$.

It can be released into the air; particularly when there is heavy vehicular traffic, water either surface or groundwater, 
and soil at places where it is produced or used.Toluene can enter the body from the air, water, or soileither outdoor or indoor. Inhalation, dermal exposure andingestion food or drink containing toluene are possible when using these products. Then, it is taken directly into the bloodstream from lungs, skin or GIT ${ }^{[7]}$.

Toluene and other inhalants have a particular problem with minors because they are widely used, easily accessible, and inexpensive $\mathrm{e}^{[8]}$.

Regarding the toluene, it is a systemic toxicant that affects many organs as liver, kidney and the central nervous system and cause immunedysfunction.Nervous system effects may be sleepiness, headaches, dizziness, unconsciousness, in-coordination, dementia, cognitive impairment, and vision and hearing loss; all may become permanent with repeated exposure. Also, it can readily affect nerve myelination or cross the blood-brain barrier $^{[9-14]}$.

High levels of toluene exposure during pregnancy, may lead to retardation of mental abilities and growth in children. Moreover, it can impair the ability to think clearly. Human reproductive process and development consists of proliferation, migration, differentiation and organogenesis that may be affected by environmental chemicals at different levels that oppose exact biological process ${ }^{[15]}$.

These effects depend on the amount taken, period of exposure and age. It was reported that, long-term daily exposure to toluene in the workplace can cause tiredness, confusion, weakness, memory loss, nausea, loss of appetiteand some hearing and color vision loss. Furthermore, it may permanently damage the brain, speech, vision, or hearing and can cause loss of muscle control, loss of memory, poor balance, and decreased mental ability ${ }^{[16]}$.

Toluene has an inhibitory effect on LH and FSH secretion at the pituitary cells or inhibition of hypothalamicgonadotropic releasing hormone $(\mathrm{GnRH})$ release.Moreover, in female rats, exposure to toluene reduces GnRH content in the preoptic area of the hypothalamuswhile in male rats it alters hypothalamic noradrenalineand the primary neurotransmitterinvolved in regulation of GnRH.Also, the hypothalamic pituitary adrenal axis reacts to stress mainly chemical toxins like toluene. So, toluene has an anti-gonadotropic effect and may cause long-term endocrine disturbances ${ }^{[17-21]}$.

However, little is known about the exact effect on the cells of anterior pituitary gland in humans and in animal models after toluene exposure. Also, no adequate studies were found about the effect of toluene on the morphological and histological structure of the pituitary cells.

Therefore, the goal of the current study was to assess the ultra-structural study of the pars distaliscells after toluene exposure in adult male albino rats. In addition, a biochemical study of pars distalis after toluene was done to correlate any biochemical changes with the histological alteration as a trial to know the possible mechanism behind these changes.

\section{MATERIALS AND METHODS}

\section{Chemicals}

Toluene (C6H5CH3) was purchased from ElGomhouria Company for Trading Chemicals and Medical Appliances in the form of a clear colorless liquid with pungent benzene like odor.

\section{Animals}

TThe current study was carried out on 20 adult male albino rats weighing (180-200 gm each). The rats were obtained from Animal House of Faculty of Medicine, Alex Universityin accordance with the institutional guidelines for animal care and use for scientific research.

Rats were located in healthy appropriately good air houses. The animals were given food and water ad libitum (fed and drink as they wish) during the experimental period and left for 2 weeksfor environmental adaptation. Then, the rats were randomly divided into two equal groups:

Group I (Control group): is consisted of 10 rats, that permitted to fed ad libitum without toluene exposure.

Group II (experimental group): The rats of this group were exposed once a day to vapors of toluene (1000 ppm) for 15 minutesfor 45 days.

\section{Exposure technique}

Each rat of the experimental group was kept in a closed exposure box with dimensions $40 \mathrm{~cm}$ length, $30 \mathrm{~cm}$ breadth and $20 \mathrm{~cm}$ height during the time of exposure. The concentration of toluene in the chambers was calculated in the faculty of Science physical chemistry unit (Chemistry Department) Alex University ${ }^{[23]}$.

To obtain $1000 \mathrm{ppm}$ of toluene vapor, $12.4 \mathrm{ml}$ of toluene solution was used. The calculated amount of toluene was put in a heated closed flask connected to the chamber by a tube in on side of the upper surface and an area of $2 \mathrm{~cm}$ $\mathrm{X} 4 \mathrm{~cm}$ was left for ventilation in the opposite side. Soda lime was put on the bottom of the chamber to absorb carbon dioxide produced by the animals and changed every day ${ }^{[24]}$.

At the end of the experiment, all the animals (control and experimental) dissectedunder ether anesthesia at a same time in the morning to avoid diurnal rhythm variation. Blood samples were taken from the heart chambers of all rats for biochemical assessment of the thyroid stimulating hormone (TSH), follicle stimulating hormone (FSH), luteinizing hormone (LH), adrencorticotrophic hormone $(\mathrm{ACTH})$, growth hormone $(\mathrm{GH})$ and prolactin hormones in both control and experimental groups.

Statistical analysis was done using student's t-test to evaluate the serum levels of the considered hormones in toluene inhaled groups in comparison with their control levels.According to the probability, the least significant level used was at $p \leq 0.05$. 
Then the animals were perfused with $4 \%$ paraformaldehyde in $0.1 \mathrm{M}$ sodium phosphate buffer at $\mathrm{pH}$ 7.4 containing $2.5 \%$ gluteraldehyde solution. Head bones were opened and the anterior lobes of pituitary glands were immediatelydissected out. Each specimen was separated into two parts; one processed for paraffin sections that were stained with hematoxylin and eosin $(\mathrm{H} \& \mathrm{E})^{[25,26]}$.

Andthe other half was subdivided into tiny pieces, managed and embedded in Epon. Semithin sections were cut and stained with toluidine blue to choose the selected area. Ultrathin sections were cut and stained by a double staining technique of uranyl acetate and lead citrate solutions to be examined by electron microscope ${ }^{[27]}$; in Electron Microscope Unit, Faculty of Medicine, Tanta University.

\section{RESULTS}

During the experiment, no death occurred in the rats of control group, but in the experimental group, one rat died after one week of toluene exposure and two rats at the $20^{\text {th }}$ days of the exposure ( $30 \%$ mortality).

\section{Biochemical and Statistical Results}

There was a highly significant reduction in mean plasma level of GH and TSH and a significant decrease in the plasma level of the FSH and LH hormones in the tolueneexposed group as compared to the control one. However, there wasa non-significant reduction in the ACTH level and prolactin in toluene-exposedratscomparing with the control animals (Table 1 and Histograms 1 and 2).

\section{Microscopic Results}

\section{A. Control Group}

Light and electron microscopic results of all specimens of the control group showed the normal structure which is specific for pars distalis of the anterior lobe of pituitary gland. It showed clusters of two main populations of cells, those with faint staining cytoplasm; chromophobes and those with strongly staining cytoplasm; chromophils. The smallest cells were the chromophobes which formed about half of the cells. The other half waschromophils which were larger, and were divided according to their staining into acidophils and basophils (Figure 1).

The acidophils were small and had acidophilic cytoplasm and eccentric pale nuclei. The basophils were large and had basophilic granular cytoplasm and eccentric nuclei. The cells were arranged in cords and were separated by blood sinusoids (Figure 1).

With electron microscope, the chromophobes were small cells spread with no specific granules, while other cells (chromophils) clarified specific secretory granules. The granules of each cell type had a distinctive size, shape and electron density by which the different cell types can be detected with electron microscopy in addition to the structural morphology of mitochondria (Figure 2).
Somatotrophs were the commonest cells that making up the main bulk of the granular cells of pars distalis. Their nuclei were spherical with a visible nucleolus and extended chromatin. The mitochondria and rER were poor as the cells were packed with secretory granules. Their secretory granules were multiple, large and spherical with uniform electron density and occupied all cytoplasm (Figure 2).

The gonadotrophs were rounded cells and had secretory granules which were electron dense, spherical, smaller than somatotrophs and changeable in their size within the similar cell. The thyrotrophs were large elongated or triangular shaped cells with long mitochondria and eccentric nuclei with a rim of heterochromatin adheres to the inner surface of the nuclear membrane. They had very small spherical secretory granules, equal in size, and were peripherally located. The cells had a rich fenestrated capillary network (Figure 2).

Corticotrophs were medium sized elongated cells with large central nucleus and dense rounded or slightly elongated mitochondria. They had diminutive, dense, uniform and rounded granules at the most outer part of the cell (Figure 3).

Mammotrophs (Lactotrophs) contained spread short and long extended cisternae of rERall over the cytoplasm and mitochondria. Their secretory granules are electron dense, pleomorphic in shape and size and collected at the periphery of the cell. All cells are separated with fenestrated capillaries (Figure 3).

\section{B. Toluene Exposed Group}

In $\mathrm{H}$ and $\mathrm{E}$ stained sections of toluene-exposed group, there was variable changes among the animals both in pattern and severity. Complete loss of normal architecture in many areas was observed to the extent that some cells were faint stained and seemed to be as chromophobes, some showed vacuolated cytoplasm and others were shrunken and had asymmetrical nuclei (Figure 4).

With electron microscope, most of cells were difficult to identify and can't distinguish from each other and appeared similar to chromophobes as they exhibited few nonspecific granules. Some of their mitochondria were swollen with loss of their cristae, while others were accumulated and became denser. They showed also irregular nuclei and apparent dilated rough endoplasmic reticulum (Figures 5,6).

Some secretory cells can be detected and differentiated from each other by their characteristic granules and their specific mitochondria in spite of structural changes. Regarding the somatotrophs, most of them revealed an irregular nuclei and a decrease in the number of their specific secretory granules with accumulation at the outer portion of cells. Their cytoplasm revealed rarefication and swollen vacuolated mitochondria. Other adjacent cells became smaller with loss of most of large secretory granules and had swollen mitochondria and irregular nuclei with more condensed chromatin (Figures 7,8). 
Gonadotrophs of the similar group revealed swollen mitochondria with loss of their internal cristae, a decrease in the number of their specific granules especially the large ones and showed few scattered small granules (Figures 8,9). Most of thyrotrophs revealed cytoplasmic changes in the form of swollen vacuolated mitochondria with loss of their internal cristae and a decrease in the number of secretory granules while the nuclei were still more or less as in control group (Figure 9).

Few thyrotrophs with their characteristic triangular shaped revealed specific small uniform secretory granules, swollen vacuolated mitochondria and more condensed chromatin in their nuclei (Figure 10).

Concerning the mammotrophs, the most obvious changes was in their mitochondria, most of them were swollen, increased in size (hypertrophic) with loss of internal cristae, few scattered dilated rER and irregular variable sized granules were also seen (Figure 11).

Most of the corticotrophs of the animals of this group presented normal characteristics when compared to the control group (Figure 12).

Some cells were affected to a large extent astheyhad vacuolated cytoplasm, shrunken asymmetrical nucleus with more thickened chromatin and few spread secretory granules (Figure 13).

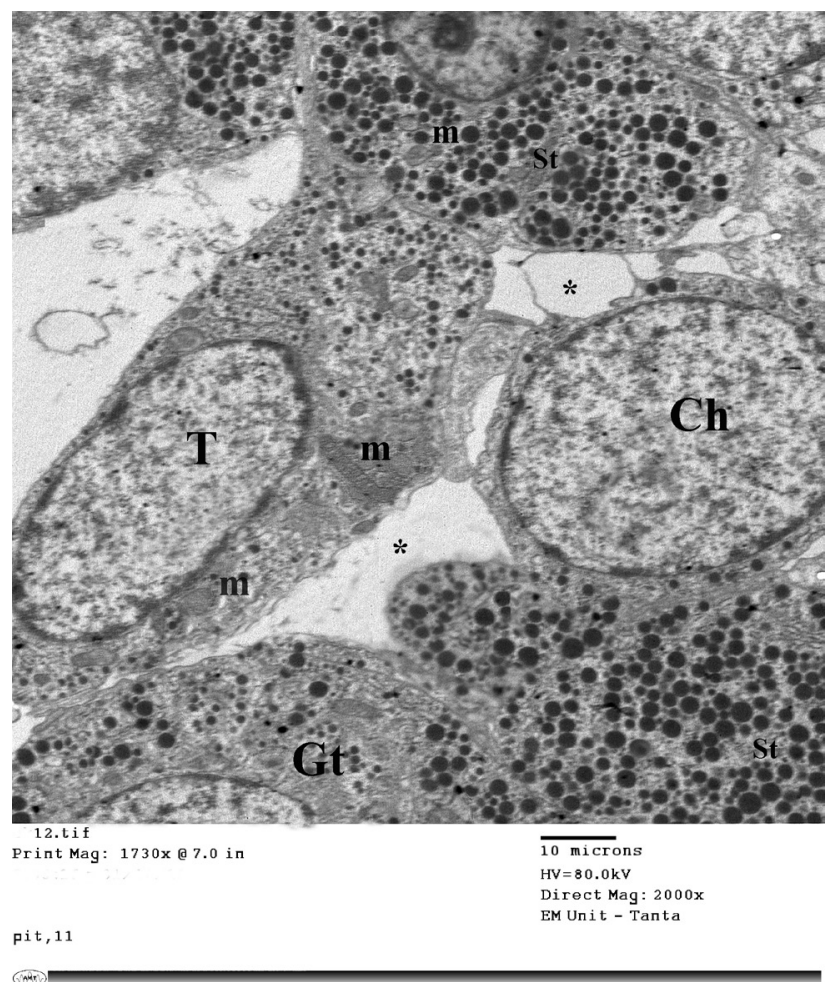

Fig. 2: An electron micrograph of an ultrathin section in the control adult rat pars distalis of pituitary gland showing a chromophobe cell $(\mathrm{Ch})$ with no specific granules, somatotrophs (St) with normal few mitochondria (m) and dense large spherical secretory granules, a gonadotroph cell (Gt) with smaller, circular, and variable sized granules in the same cell and a large elongated triangular shaped a thyrotroph cell $(\mathrm{T})$ with eccentric nucleus, dark elongated mitochondria (m) and peripheral small spherical uniform in size secretory granules. Notice the blood sinusoid (*) (X2000).

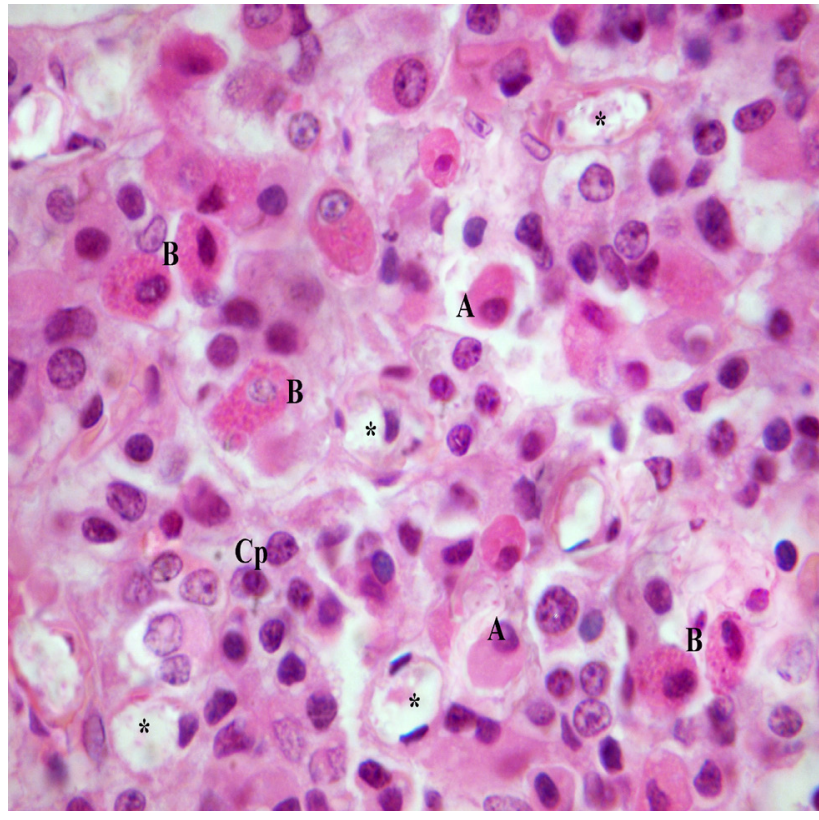

Fig. 1: A photomicrograph of a section in the control adult rat pars distalis of pituitary gland showing clusters of two main populations of cells; those with strongly staining cytoplasm \{chromophils; acidophils (A) with acidophilic cytoplasm and eccentric nuclei and basophils basophilic granular cytoplasm and eccentric nuclei (B) $\}$ and those with weakly staining cytoplasm (chromophobes $\mathrm{Cp}$ ). Notice the blood sinusoids (*). (H\&E X1000)

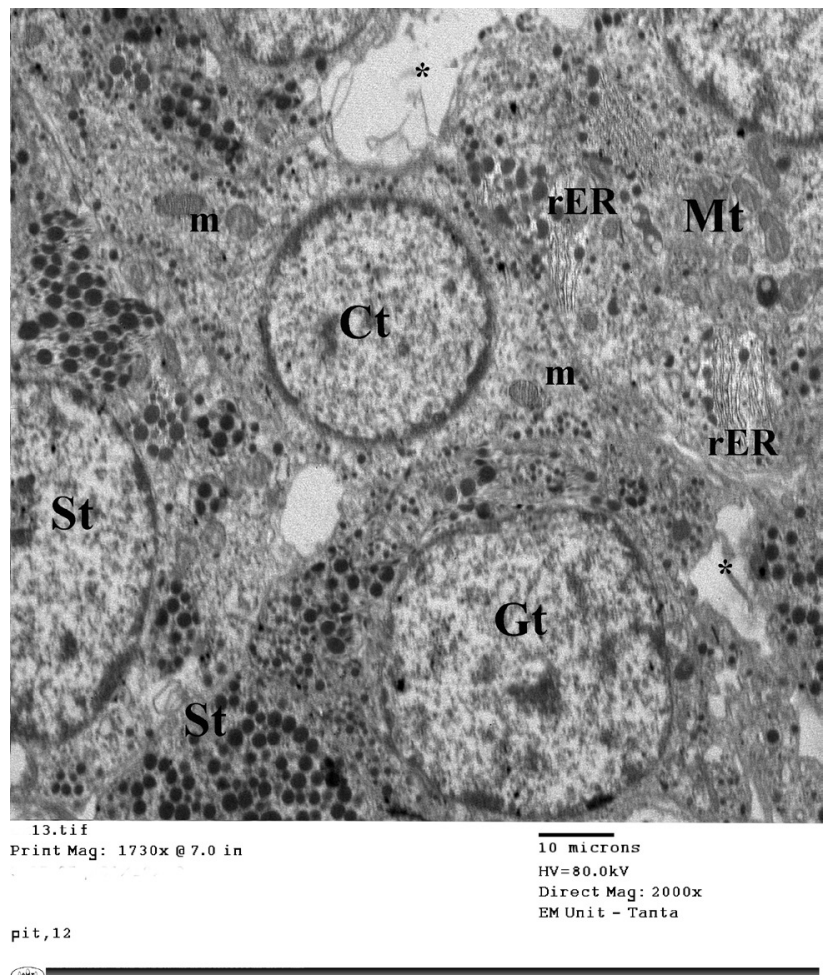

Fig. 3: An electron micrograph of an ultrathin section in the control adult rat pars distalis of pituitary gland showing an elongated corticotroph $(\mathrm{Ct})$ with central nucleus, dense oval mitochondria $(\mathrm{m})$ and small sparse dense uniform secretory granules located at the extreme periphery, a mammotroph (Mt) with scattered rER, mitochondria and secretory granules pleomorphic in size and shape. Notice the blood sinusoid (*), somatotrophs (St), gonadotroph (Gt) with their characteristic features. (X2000) 


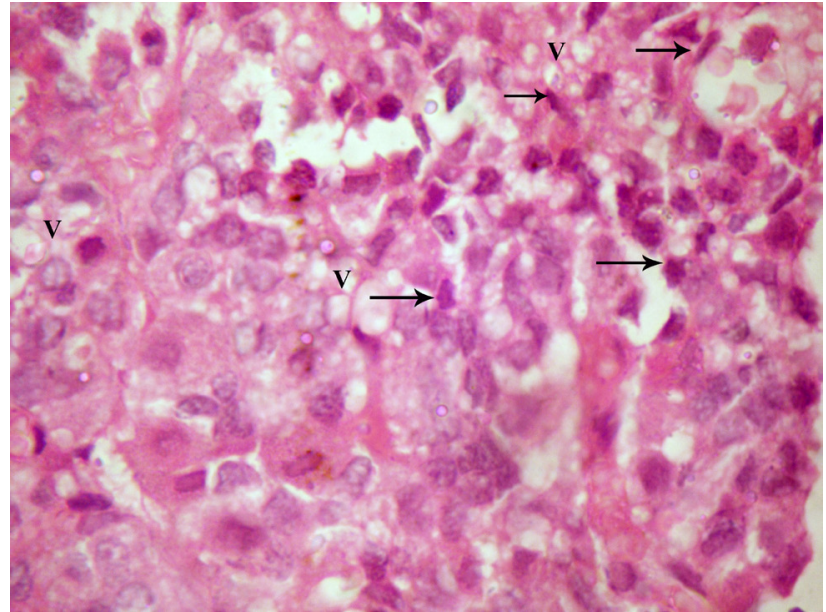

Fig. 4: A photomicrograph of a section in the toluene-exposed adult rat pars distalis of pituitary gland showing loss of normal architecture. It showed vacuolated cells (V) among many shrunken cells with small irregular nuclei $(\rightarrow)$ (H\&E X1000).

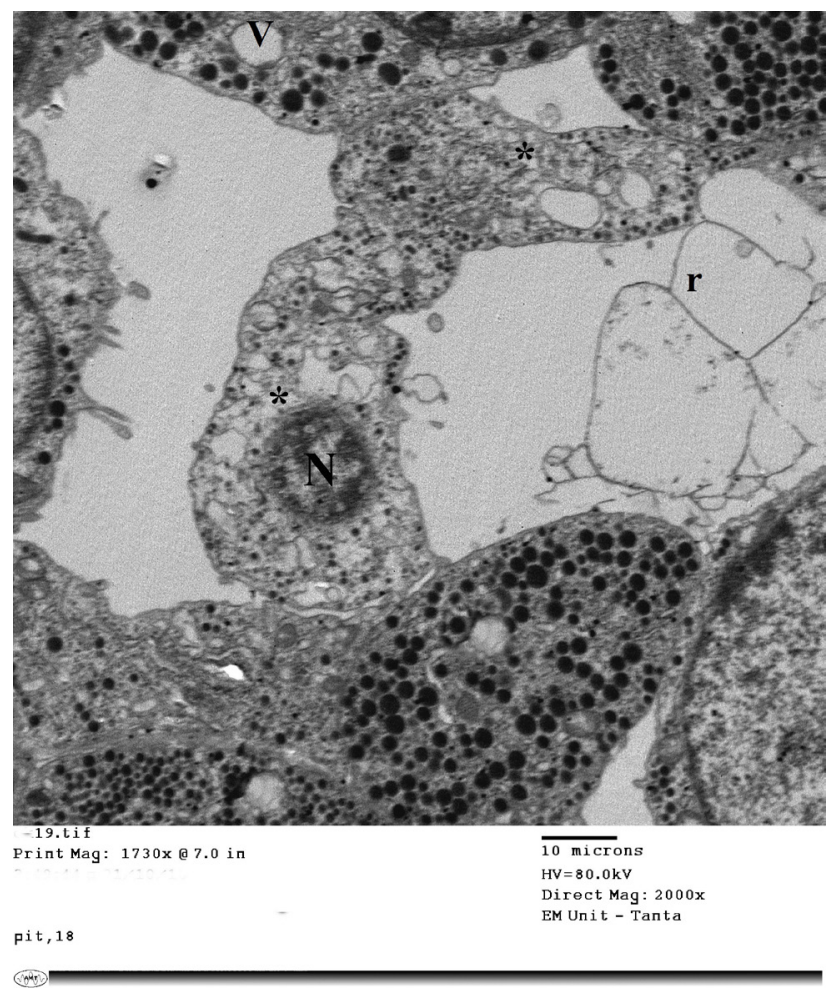

Fig. 5: An electron micrograph of an ultrathin section in the tolueneexposed adult rat pars distalis of pituitary gland showing cells with vacuolated (v) and rarefied (r) cytoplasm, and few non-specific granules. Notice small nucleus with more condensed chromatin (N) (X 2000).

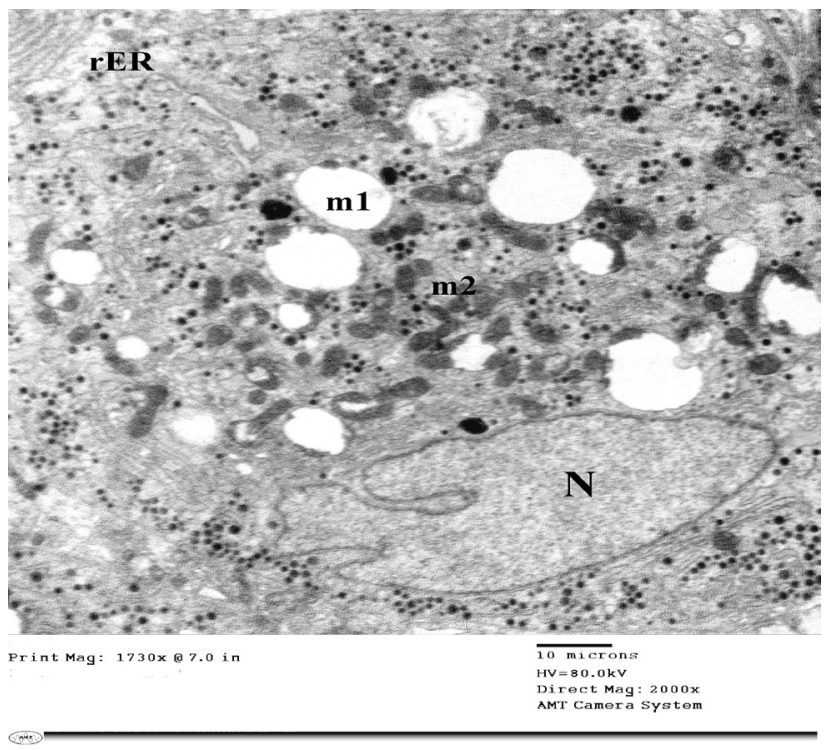

Fig. 6: An electron micrograph of an ultrathin section in the tolueneexposed adult rat pars distalis of pituitary gland showing cells with non-specific granules and irregular nucleus $(\mathrm{N})$. Notice vacuolated mitochondria $(\mathrm{m} 1)$, denser mitochondria $(\mathrm{m} 2)$ and dilated rough endoplasmic reticulum (rER) (X 2000).

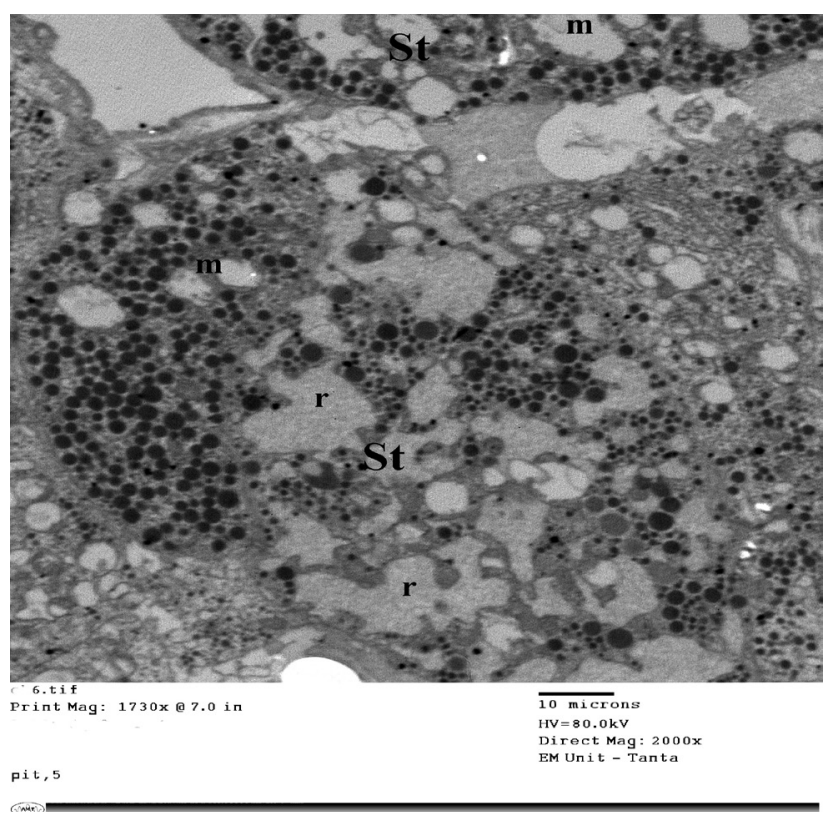

Fig. 7: An electron micrograph of an ultrathin section in the tolueneexposed adult rat pars distalis of pituitary gland showing somatotroph (St) with swollen vacuolated mitochondria (m), rarefied cytoplasm (r) and peripheral secretory granules (X 2000). 


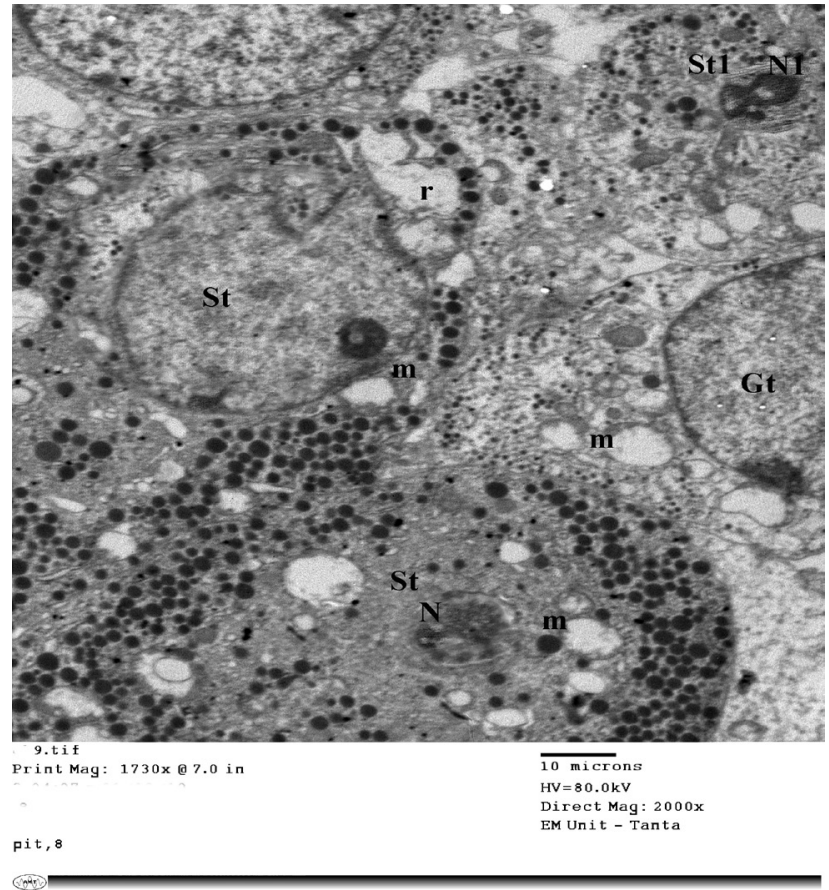

Fig. 8: An electron micrograph of an ultrathin section in the tolueneexposed adult rat pars distalis of pituitary gland showing somatotrophs (St) with peripheral secretory granules, irregular nuclei $(\mathrm{N})$, rarefied cytoplasm (r) and swollen vacuolated mitochondria. Some somatotrophs (St1) became small with loss of most of large secretory granules and showed small irregular nucleus with more condensed chromatin (N1). A gonadotroph $(\mathrm{Gt})$ is noticed exhibiting few scattered small granules and swollen mitochondria with loss of their cristae (m)(X 2000).

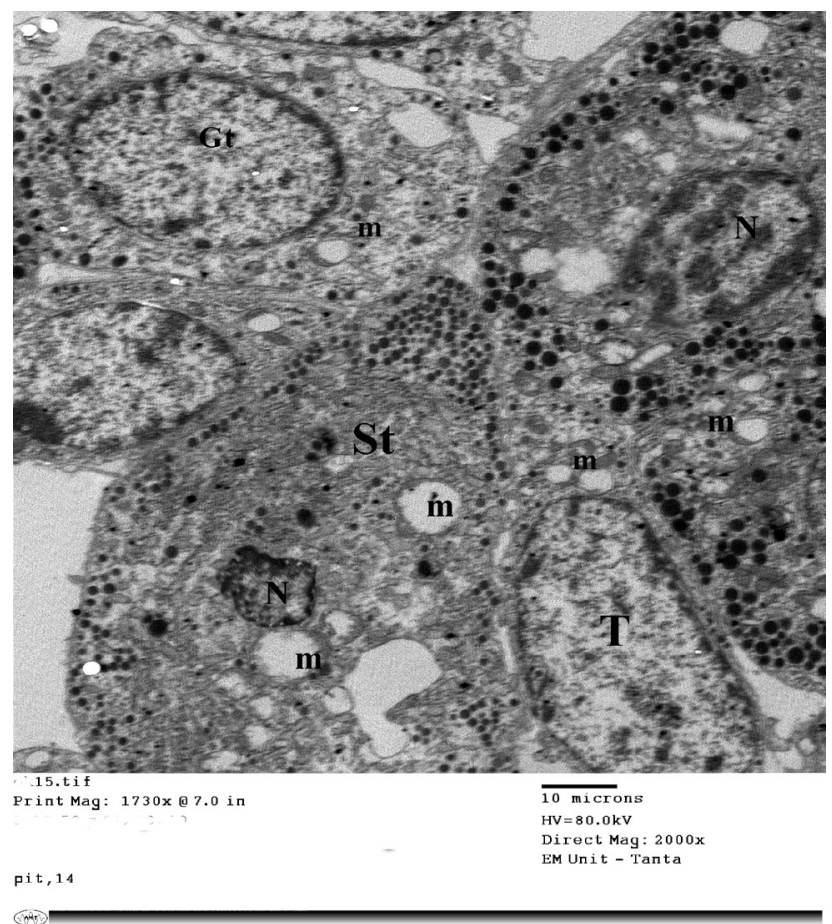

Fig. 9: An electron micrograph of an ultrathin section in the tolueneexposed adult rat pars distalis of pituitary gland showing a gonadotroph (Gt) with a reduction in granules and vacuolated mitochondria (m), a thyrotroph (T) with few peripheral secretory granules and vacuolated mitochondria (m). Notice many parts of somatotrophs (St) with reduction of their secretory granules, vacuolated mitochondria $(\mathrm{m})$ and irregular nuclei with more condensed chromatin (N). (X 2000).

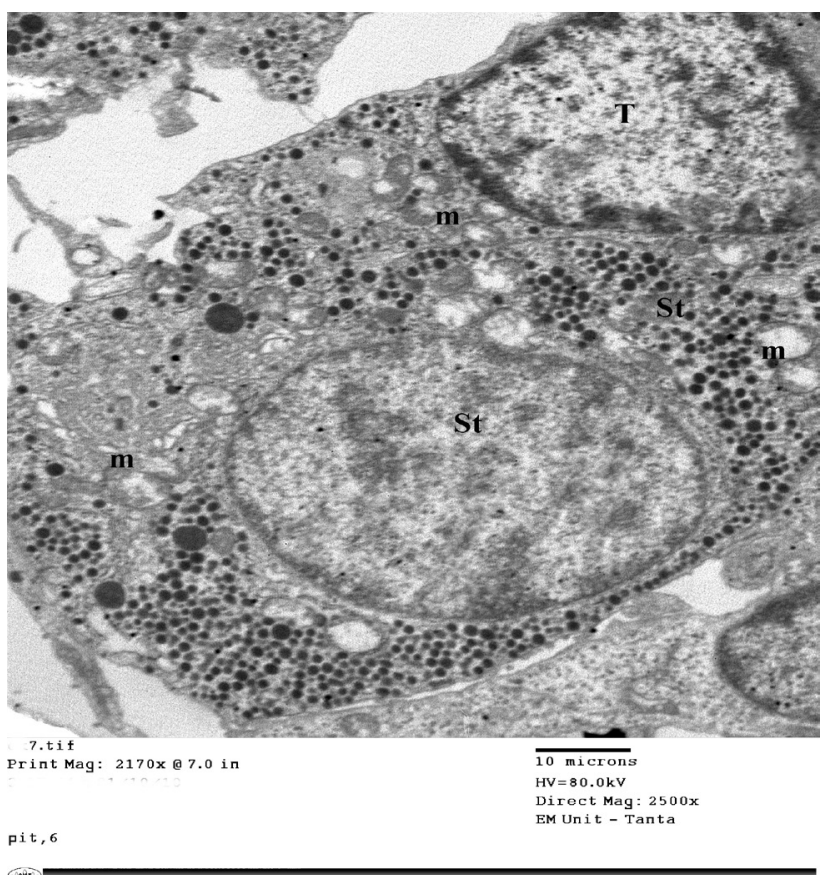

Fig. 10: An electron micrograph of an ultrathin section in the tolueneexposed adult rat pars distalis of pituitary gland showing a triangula thyrotroph $(\mathrm{T})$ had eccentric nucleus with more condensed peripheral chromatin, vacuolated mitochondria with loss of their oval shape (m), peripheral specific secretory granules. Somatotrophs $(\mathrm{St})$ are noticed exhibiting a reduction in the large granules and showed many peripheral small secretory granules (X 2000).

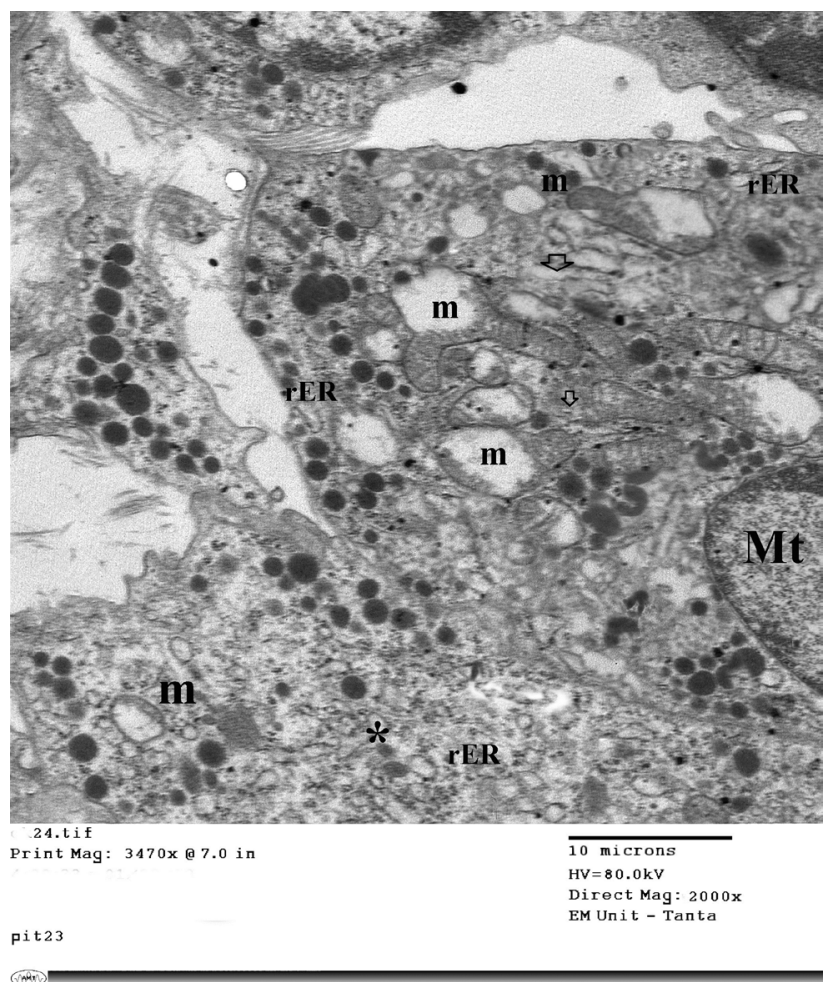

Fig. 11: An electron micrograph of an ultrathin section in the toluene-exposed adult rat pars distalis of pituitary gland showing a mammotroph (Mt) with irregular variable size granules, few dilated rER and swollen hypertrophied vacuolated different size mitochondria with loss of their internal cristae (m) Notice adjacent cell (head arrow) with swollen mitochondria (m), scattered dilated rER and non-specific granules (X 2000). 


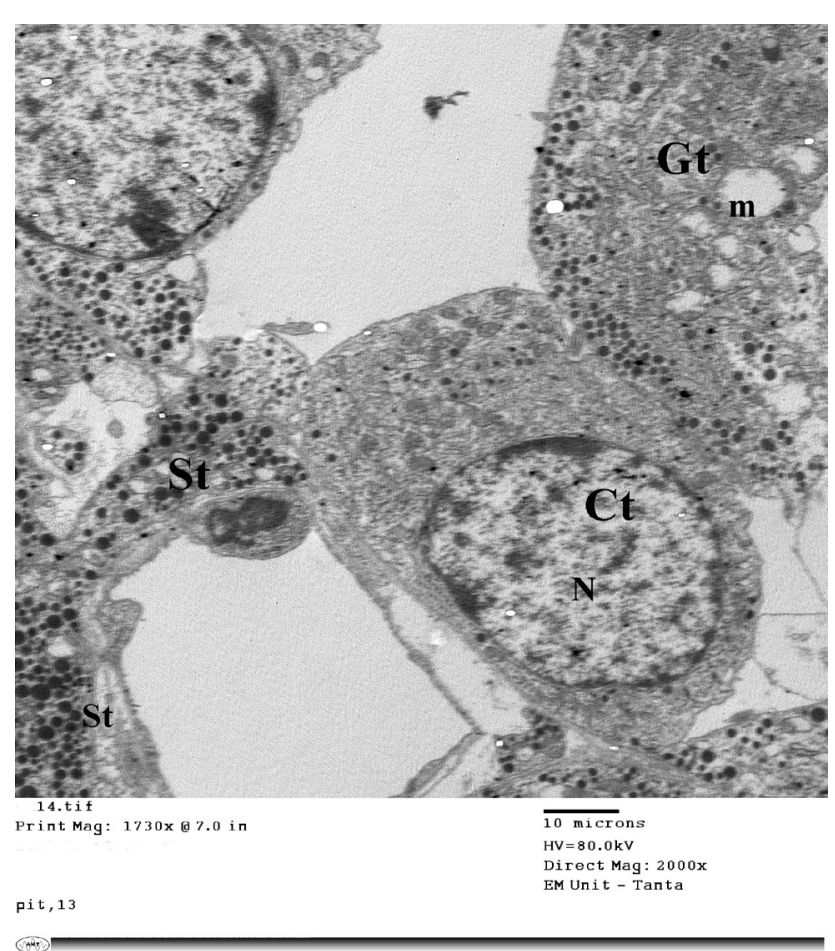

Fig. 12: An electron micrograph of an ultrathin section in the tolueneexposed adult rat pars distalis of pituitary gland showing a corticotroph $(\mathrm{Ct})$ with normal nucleus $(\mathrm{N})$ and secretory granules at the extreme peripherally. Notice the surrounding somatotrophs (St) with small nucleus with condensed chromatin, and gonadotrophs (Gt) with few granules and vacuolated mitochondria (m) (X 2000).

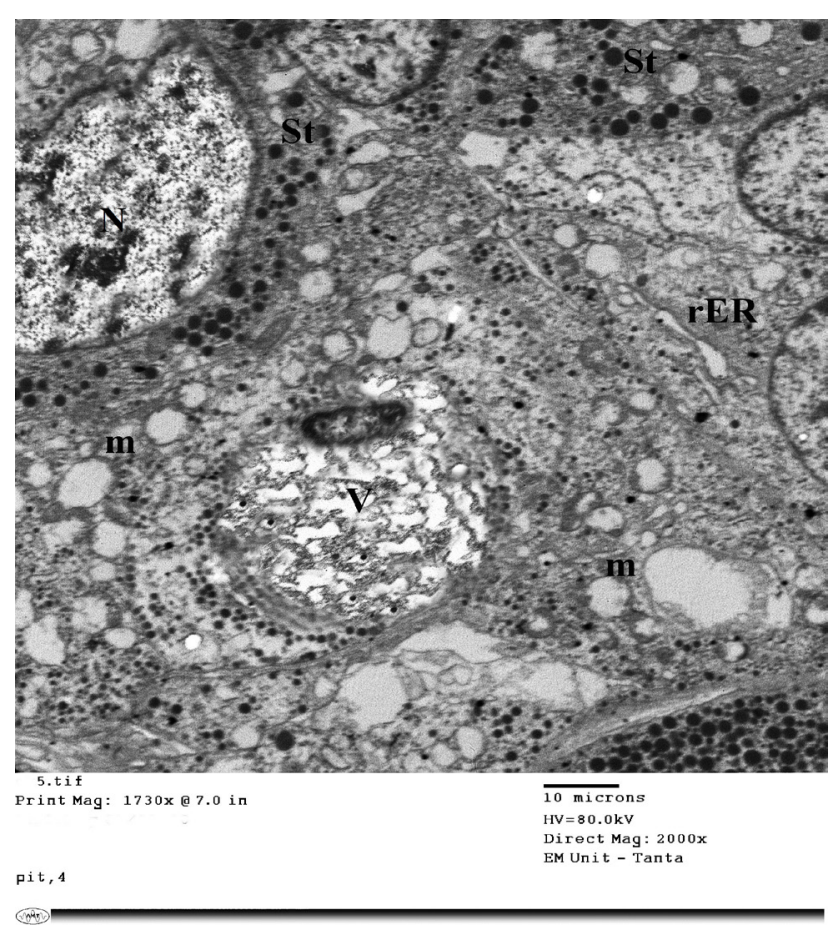

Fig. 13: An electron micrograph of an ultrathin section in the tolueneexposed adult rat pars distalis of pituitary gland showing indefinite cells with vacuolated cytoplasm (V), vacuolated mitochondria (m) few scattered secretory granules and scattered dilated rough endoplasmic reticulum (rER) among somatotrophs $(\mathrm{St})$. Notice somatotrophs (St) with affected mitochondria and irregular shrunken nucleus with more condensed chromatin (N). (X2000).
Table 1: showing the mean serum level of different hormones of pars distalis in different groups

\begin{tabular}{|c|c|c|c|c|}
\hline & \multicolumn{2}{|c|}{ Mean \pm SD } & \multirow{2}{*}{$\mathrm{t}$} & \multirow{2}{*}{$\begin{array}{c}\text { P } \\
\& \\
\text { Significance }\end{array}$} \\
\hline & Control & Toluene-exposed & & \\
\hline $\begin{array}{c}\mathrm{GH} \\
\mathrm{ng} / \mathrm{ml})\end{array}$ & $0.74 \pm 0.23$ & $0.35 \pm 024$ & 3.41 & $<0.001 \mathrm{HS}$ \\
\hline $\begin{array}{c}\text { TSH } \\
(\mu \mathrm{IU} / \mathrm{mL})\end{array}$ & $0.190 \pm 0.01$ & $0.057 \pm 0.04$ & 9.49 & $<0.001 \mathrm{HS}$ \\
\hline $\begin{array}{c}\text { FSH } \\
(\mathrm{mIU} / \mathrm{mL})\end{array}$ & $1.467 \pm 0.107$ & $0.881 \pm 0.619$ & 3.1 & $<0.05 \mathrm{~S}$ \\
\hline $\begin{array}{c}\mathrm{LH} \\
(\mathrm{mIU} / \mathrm{mL})\end{array}$ & $0.796 \pm 0.016$ & $0.466 \pm 0.333$ & 3.07 & $<0.05 \mathrm{~S}$ \\
\hline $\begin{array}{l}\text { ACTH } \\
(\mathrm{pg} / \mathrm{ml})\end{array}$ & $60 \pm 2.58$ & $40.60 \pm 28.4$ & 2.09 & $>0.05 \mathrm{NS}$ \\
\hline $\begin{array}{l}\text { Prolactin } \\
(\mathrm{ng} / \mathrm{mL})\end{array}$ & $8.65 \pm 0.36$ & $5.82 \pm 4.02$ & 2.23 & $>0.05 \mathrm{NS}$ \\
\hline
\end{tabular}

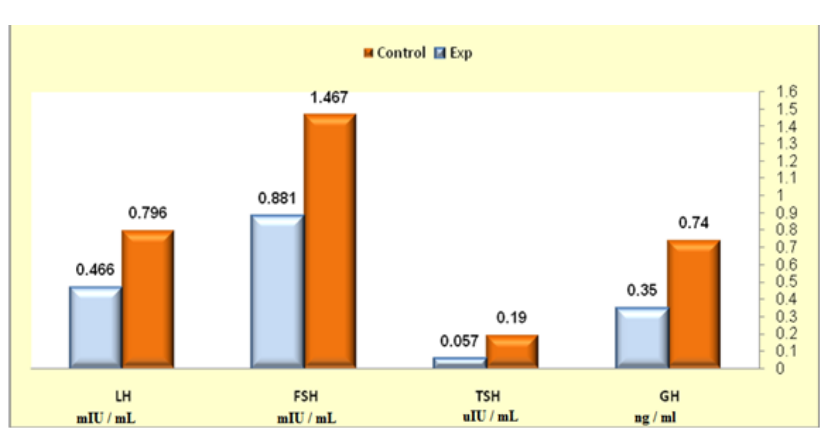

Histogram 1: showing the mean serum level of "GH, TSH, FSH, and LH" hormones in control and toluene exposed group

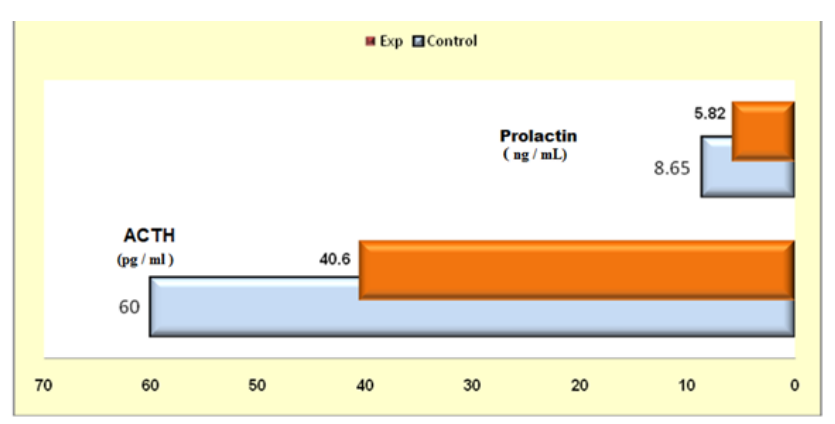

Histogram 2: showing the mean serum level of "ACTH and Prolactin" hormones in control and toluene exposed group

\section{DISCUSSION}

Toluene is one of the most commonly used substances in industry and commerce. Chronic toluene exposures induce toxicity and severe adverse outcomes as it has a low viscosity and is absorbed systematically. Human exposures have the potential to cause significant morbidity and mortality and this explained the high mortality rate $(30 \%)$, which found in this study during toluene exposure. It was established that the cause of death may be due to cardiopulmonary failure or pulmonary edema (Prayulsatien W, 2013, Mukai M et al., 2014 and William K. et al., $2016^{[2,28,29]}$ 
The endocrine glands; including adrenal, pituitary, thyroid, parathyroid, endocrine part of pancreas, testis and ovary can be affected by various industrial solvents, in human and experimental animals. The pituitary gland hormones are specifically changes after toluene exposure (Yeshvandra et al 2009)[30].

Therefore, the present study was a trial to throw the light on the effect of toluene on the pars distalis cells of the anterior pituitary gland of adult male albino rats that liberated hormones and correlate any biochemical alterations with histological changes.

In this study, there was a significant reduction in mean plasma level of most of liberating hormones from pars distalis ( $\mathrm{GH}, \mathrm{TSH}, \mathrm{FSH}$, and $\mathrm{LH})$ and a non-significant reduction in ACTH and prolactin, in the toluene-exposed group comparing with the control one. These biochemical results are coincided with the von Euler et al. (2000) and Yilmaz et al. $(2001)^{[20,21]}$ and are in parallel with the microscopic results in this work that showed most of cells were more or less similar to chromophobes, appeared pale with lightly stained vacuolated cytoplasm with no or few non-specific granules.

Regarding the ultrastructural changes in the present work, most of cells revealed degranulation and cannot distinguish from each other and there was a raise in the chromophobes-like cells. This result may suggest hyper-function and exocytosis of the secretory granules. Regarding chromophobes and the non-identified cellular population, they represent the immature cells with limited secretory granules and degranulated forms of chromophiles, whereas any alteration of chromophobes amount is due to an increase or decrease of degranulatedchromophiles (Afifi, OK 2010) ${ }^{[31]}$.

In addition to the morphological changes that suggested exocytosis and hyper function, other cells showed some degenerative changes, in the form of cytoplasmic vacuolation, rarefication with distorted cellular construction, irregular shrunken nuclei with more condensed chromatin as well as swollen mitochondria with lysis of their mitochondrial. It is well documented that strong hormone production may cause oxidative stress due to arising of lipid peroxidation with production of reactive oxygen species (ROS) and toxic derivatives (Marie et al. $2007)^{[32]}$.

This ROS accumulation produces a strong harmful effects on the cells specifically phospholipids of biological membrane, proteins and DNA. Although the mitochondria are the principal site of ROS generation in cell, they are also the main target for the free radicals that leads to damage of mitochondrial respiratory chain with consequent increase in ROS generation and so on (Szewczyk et al., 2002) ${ }^{[33]}$.

In the current work, it was found that the most affected organelle in the pars distalis cells was the mitochondria, which is confirmed the ROS generation as a mechanism of cellular degeneration.
Concerning the somatotrophs, most of them revealed degenerative changes, reduction in the number of the specific secretory granules and their accumulation at the outer boundary of cells. Others became smaller with disappearance of most of large secretory granules and had edematous swollen mitochondria as well as irregular nuclei with more condensed chromatin. These results are in parallel with a highlysignificant reduction in $\mathrm{GH}$ in this work and are coincided with (Mancini et al., 2018) ${ }^{[34]}$ who found that growth hormone deficiency is associated with a different pattern of plasma antioxidants, suggesting inadequate reactivity toward radical production rather than an antioxidants consumption.

Regarding the gonadotrophs, a reduction in their secretory granules in the toluene-exposed rats in this work run in parallel with a significant decrease in the plasma level of FSH and LH. These results are in agreement with Layla A Kareem et al(2014), and Yamada, (1993) ${ }^{[35,36]}$ who found that toluene causes a reduction in LH secretion from the anterior pituitary which in turn suppresses testosterone production.

Similarly, studies of reproductive endocrine function in male workers subjected completely to toluene revealed a decrease in $\mathrm{LH}, \mathrm{FSH}$, and testosterone concentrations Svensson et al (1992). Beckett et al(1997). and Yilmaz et al, 2001 ${ }^{[37,38,21]}$ suggested that a reduced release of GnRH neurons is the major factor responsible for the gonadotropin loss after toluene exposure, in addition to its inhibitory effect on pituitary sensitivity to GnRH besides interference with complex regulated hormonal messenger system. They concluded that toluene has an antigonadotropic action and it may lead to prolonged endocrine defect in male rats.

Formerly, Ameno et al (1992 ${ }^{[17]}$ depending on the neuroanatomical studies in both humans and animals, concluded that the toluene essentially released into the brainstem, including the hypothalamus. Then, Ulrike et al (1999) ${ }^{[8]}$ added that the reduced secretion of LH and FSH were not because of the hypothalamic actions of toluene, but rather because of the pituitary which do not happened acutely, such as change of gonadotropin subunit transcription or translation.

A highly significant reduction in mean plasma level of TSHin this work is coincided with a decrease in the number of secretory granules in thyrotrophs in this work. This decrease in TSH expected to increase the thyroid hormones via normal negative feedback between thyroid hormones and TRH then TSH. Conversely, Singh et al. $(2000)^{[39]}$ reported that exposure to the organic solvents increases the pituitary secretion of TSH and reduces serum T3 and T4 levels due to suppression of the response of thyroid-to-thyroid stimulating hormone.

In addition, National Toxicology Program, 2006 ${ }^{[40]}$ found that toluene has been shown to affect dopaminergic and adrenergic turnover within variable area of the brain. The neurotransmitter influence causes unhealthy secretion of pituitary hormones resulting in temporal central hypothyroidism. 
This discrepancy may be clarifiedby suggestion of Afifi, OK 2010 ${ }^{[31]}$ that overproduction of type-2iodothyronine deiodinase enzyme and its mRNA level that induce a high concentration of T3 in the hypothalamus. This local hyperthyroid condition leads to suppression of TSH production and release.

Furthermore,Widad J. et al., 2012 $2^{[41]}$ explained that the oxidative stress and insufficient antioxidant defense cause a loss of thyroid hormone-binding proteins, reduction in thyroid function, and a decrease in serum T3 and T4 levels, which in turn causes several biochemical changes in the tissues that predispose them to more oxidative damage.

Concerning the mammotrophs, the most obvious change was in their mitochondria, most of them were swollen and edematous, larger with disappearance of internal cristae in addition to presence of irregular uneven granules. Biochemically, a non-significant decrease in prolactin level in toluene-exposed rats was found. These were somewhat in parallel with Soberanes et al., $(2013)^{[42]}$ who found that toluene stress exposure during pregnancy in mice decreases prolactin levels poor lactation and deficient body weight gain in dams.

Considering the corticotrophs of the toluene exposed animals, most of them were more or less as in control group, although few cells had vacuolated cytoplasm, shrunken nucleus and few spread secretory granules. Correspondingly, a non-significant reduction in the ACTH levelwas found in toluene exposed animals in this work.

These results were partially parallel with the results of DwiKesuma et al(2005) $)^{[43]}$ who found that inhalation of toluene prior to formaldehyde exposure had no effect on hypothalamic pituitary adrenal axis (HPA axis). Also, Palermo et al, 2001 ${ }^{[44]}$ and hanaa et al (2009) ${ }^{[45]}$ established that toluene inhalation causes a significant increase in serum corticosterone level and explained that this increase is due to the indirect effect of toluene on microphage/ lymphocyte activity via stress induction and hence a secretion of ACTH and corticosterone.

Moreover, Gotohda et al (2005) $)^{[46]}$ demonstrated a significant increase in the weight of adrenal gland, hypertrophy of the adrenal cortex and spreading out of the corticosterone-positive area in rats subjected to toluene.

\section{CONCLUSION}

Toluene exposure induced morphological changes in most of cells of pars distalis and their secreted hormones, although few cells were less affected as corticotrophs and mammotrophs. Depended on this conclusion and because of the significant health risks associated with solvent exposure, it is recommended that, routine hormonal monitoring of exposed subjects in their work is necessary to ensure good occupational health and safety conditions. In addition, other studies at multiple levels to elucidate the mechanisms involved in mediating occupational chemical exposure effects and search for earlier and more sensitive biomarkers that will improve occupational safety.

\section{CONFLICTS OF INTEREST}

There are no conflicts of interest.

\section{REFERENCES}

1. Silvia L CruzMaría Teresa Rivera-García, John J. Woodward Review of toluene action: clinical evidence, animal studies and molecular targets. J Drug Alcohol Res. 2014; 3: 1-15.

2. William KBoyes, Mark Bercegeay,Laura Degn, Tracey E Beasley,Paul AEvansky, Jean Claude Mwanza,Andrew M. Geller,Charles Pinckney T Michael Nork and Philip J Bushnell. Toluene Inhalation Exposure for 13 Weeks Causes Persistent Changes in Electroretinograms of LongEvans Rat. Neurotoxicology. 2016; 53: 257-270.

3. Kurtzman TL, Otsuka KN, Wahl RA. Inhalant abuse by adolescents. Science Direct-Journal of adolescentHealth 2001; 28(3): 170-180.

4. Bratveit M, and Moen BE. Exposure to organic solvents during cosmotic finishing of cars. Occup. Med. 2001; 51(6):396-400.

5. Krone CA. (2004): Diisocyanates and nonoccupational disease: a review. Arch Environ Health, 59(6):306-16.

6. Ellenhorn MJ, SchonwaldS, Ordog G, Wusserberyer J. (1997): "Hydrocarbon products". In: medical Toxicology, diagnosis and treatment of human poisoning. Williams \& Wilkins, Philadelphia, London, Paris, Sydney, Tokyo, pp. 1420-1447.

7. Dallos P (1992):The active cochlea.J.neuros ci.,12,4575-4585.Department of health and human services, Public Health Service Agency for Toxic Substances and Disease Registry www.atsdr.cdc. gov/ September 2015, Chapter 8.

8. Ulrike Luderer, Michael S Morgan, Carl A Brodkin, David A Kalman, Elaine M Faustman. Reproductive endocrine effects of acute exposure to toluene in men and women.Occup Environ Med 1999; 56:657-666.

9. Balster, R.L. Neural basis of inhalant abuse. Drug. Alcohol Depend. 1998; 51: 207-214.

10. Berenguer P, Soulage C, Perrin D, PequignotJM, Abraini, JH. Behavioral and neurochemical effectsinduced by subchronic exposure to $40 \mathrm{ppm}$ toluene in rats.Pharmacol. Biochem. Behav. 2003; 74: 997-1003.

11. Kondo H, Huang J, Ichihara G, Kamijima M, Saito I, Shibata,E, Ono Y, Hisanaga N, Takeuchi $\mathrm{Y}$ and Nakahara D. Toluene induces behavioral activation without affectingstriatal dopamine metabolism in the rat: behavioral andmicrodialysis studies. Pharmacol. Biochem. Behav. (1995); 51: 97-101. 
12. Riegel, A.C. and French E D. An electrophysiologicalanalysis of rat ventral tegmental dopamine neuronal activityduring acute toluene exposure. Pharmacol. Toxicol 1999; 85, 37-43.

13. SeoH S, Yang M, Song M.S, Kim J S, Kim SH, Kim JC, KimH, Shin T, Wang H, Moon C. Tolueneinhibits hippocampal neurogenesis in adult mice. Pharmacol.Biochem. Behav. 2010; 94, 588-594.

14. Von Euler G1, Fuxe K, Hansson T, Ogren SO, Agnati LF, Eneroth P, Härfstrand A, Gustafsson JA.. Effects of chronic toluene exposure on central monoamine and peptidereceptors and their interactions in the adult male rat. Toxicology 1988;52:103-26.

15. Ritchie GD, Still KR, Alexander WK, Nordholm AF, Wilson CL, Rossi J 3rd Dr. A review of the neurotoxicityrisk of selected by hydrocarbon Fuels. J. Toxicol Environ health B crit Rev. 2001; 4(3): $223-312$.

16. Christopher M. Filley, William Halliday, Kleinschmidt B K ,Demasters. The Effects of Toluene on the Central Nervous System.Journal of Neuropathology and Experimental Neurolog2004; 63: 112

17. Ameno K1, Kiriu T, Fuke C, Ameno S, Shinohara T, Ijiri I. Regional brain distribution of toluene in rats and in a human autopsy. Arch Toxicol.1992; 66:153-6.

18. Stepanov MG, Altukhov VV, Prol̆mina FI, Savchenko ON, Danilova OA. Physiologic mechanisms of the reaction of the reproductive system in female rats to chronic exposure to low doses of toluene[abstract]. FiziologicheskiiZhurnal SSSR Imeni IM Sechenova1990;76:1096-102.

19. Andersson K, Fuxe K, Toftgård R, Nilsen OG, Eneroth P, Gustafsson JA. Toluene-induced activation of certain hypothalamic and median eminence catecholamine nerve terminal systems of the male rat and its effects on anterior pituitary hormone secretion. ToxicolLett .1980;5:393-8.

20. Von Euler M., Pham TM, Hillefors M, BjelkeB, Henriksson B, von Euler G. Inhalation of low concentrations oftoluene induces persistent effects on a learning retention task,beam-walk performance, and cerebrocortical size in the rat. Exp. Neurol. 2000; 163, 1-8.

21. Yilmaz B, Kutlu S, Canpolat S, Sandal S, AyarA,Mogulkoc R, Kelestimur H. Effects of paint thinner exposureon serum LH, FSH and testosterone levels and lamiccatecholaminecontents in the male rat. Biol Pharm Bull.2001; 24(2): 163-166.
22. Bjornaes $\mathrm{S}$ and Naalsund LU. Biochemical changes in different brain areas after Toluene inhalation. Toxicology.1988; (2-3): 367-374

23. Masterton WL and Hurley CN. (1997): Gas law calculation. In: Chemistry, Principles \&Reactions. A Core Text. 3rd edition. Fort Worth, Philadelphia, San Diego, New York, Orlando, Austian, San Antonio, Toronto, Montreal, London, Sydney and Tokyo. Pp.116-119 \& 255-257.

24. Obara H, Sekimoto M,Iwai S.Alternations to the bronchial and bronchiolar surfaces of adult mice after exposure to high concentration of oxygen. Thorax 1979; 34:479-489

25. Bancroft J and Gamble A (2002). Theory and Practice of Histological Techniques, $5^{\text {th }}$ ed. Churchill Livingstone, New York and London, pp. 165-175

26. Bancroft ID and Cook HC. (1994): Manual of histological techniques and their diagnostic application 4th ed. Churchill Living Stone. New York, Edinburgh, London, Madrid, Melbourne and Tokyo. P.180, $625 \& 263$.

27. Bozzola JJ and Russell LD. (1999): Electron Microscopy: Principles and Techniques for Biologists, 2nd edition, Jones and Bartlett Publishers, pp. 16.

28. Prayulsatien W: Sudden death from toluene intoxication: a case report and review of literature. J Med Assoc Thai2013; 96(9):1242-4.

29. Mukai M, Woods LW, Stump S, Ebel JG Jr, Levitt AS, Frey MW, Smith J, Uzal FA, Poppenga RH, Puschner B. Detection of diisocyanates in nesting material associated with mortality in pigeon chicks. J Vet Diagn Invest. 2014;26(2):327-33.

30. YeshvandraVerma andSuresh Ver Singh $R$ Endocrinal toxicity of industrial solvent. A mini review. Indian journal of experimental biology (2009); 47:537-49.

31. Afifi OK. Effect of long term food-restriction (lowcaloric diet) on pars distalis of the anterior pituitary gland of adult male albino rats; a biochemical and histological study. Egyptian Journal of histology. 2010, volume 33 (2), June

32. Marie-Claude B, Claude Roberg, Mélissa O, Nicole Seladin.expression in rat adrenal gland: effect of adrenocorticotropic hormone treatment. J. Endocrinol. 2007; 192: 53-66

33. SzewczykA. and Wojtczak L. (2002): Mitochondria as a pharmacological target. Pharmacological Reviews, 54(1): 101-27. 
34. Mancini A, Di Segni C, Bruno C, Olivieri G, Guidi F, Silvestrini A, Meucci E, Orlando P, Silvestri S, Tiano L, Pontecorvi A. Oxidative stress in adult growth hormone deficiency: different plasma antioxidant patterns in comparison with metabolic syndrome. Endocrine. 2018;59(1):130-136.

35. Layla A Kareem ,Hiwa B Banna, Kameel MNaoom. Effects of Toluene and Formaldehyde on Oogenesis in Adult Female Mice. Diyala Journal of Medicine.2014;6(1)

36. Yamada K. Influence of lacquer thinner and some organic solvents on reproductive and accessory reproductive organs in the male rat. Biol. Pharm. Bull. 1993; 16(4): 425-427.

37. Bengt-GöranSvensson, Gun Nise, Eva Marie Erfurth and Håkan Olsson. Neuroendocrine effects in printing workers exposed to toluene. $\mathrm{Br} \mathrm{J}$ Ind Med1992; 49:402-8.

38. Beckett JL, Sakurai H, Adams BM, Adams TE. Moderate and severe nutrient restriction has divergent effects on gonadotroph function in orchidectomized sheep. Bio Reprod. 1997; 57: 415-419.

39. Singh B, Chandran V, Bandhu HK, Mittal BR,Bhattacharya A, Jindal SK, Varma S. Impact of lead exposure on pituitary-thyroid axis inhumans. Biometals.2000;13(2): 187-192.

40. National Toxicology Program. NTP Toxicology and Carcinogenesis Studies of 2, 3, 4, 7, 8-Pentachlorodibenzofuran (PeCDF) (CAS No.
57117-31-4) in Female HarlanSprague-Dawley Rats (Gavage Studies). NatlToxicol Program Tech Rep Ser.2006; 525: 1-198.

41. Widad J. H. Ali, Ragaa KH. Ali, SaadAlfallouji .The Correlation between Oxidative Stress and Thyroid Hormones in Serum and Tissue Homogenized of Hypothyroidism Patients. Medical Journal of Babylon2012; 9:4.

42. Soberanes-Chavez P, Lopez-Rubalcava C, de Gortari P, Cruz SL. Exposure to toluene and stress during pregnancy impairs pups' growth and dams' lactation. NeurotoxicolTeratol. 2013; 40C:9-16.

43. DwikesumaSARI hypothalamic adrenal gland axis in mice inhaling toluene prior to low level long term exposure to formaldehyde. J. vet.med. sci.2005; 67(3):303-309

44. Palermo-Neto J, Santos FA, Guerra JL, Santos GO,Pinheiro SR. Glue solvent inhalation impairs host resistance to Mycobacterium bovis-induced infection in hamsters. Vet Hum Toxicol. 2001; 43(1): $1-5$.

45. Hanaa H Ahmed, Fateheya M Metwally,Hend M. Rashad .Toxicity of solvents exposure on the neuroendocrine system in rats: Role of amino acids supplementation Report and Opinion, 2009;1(4),66-83.

46. Gotohda T, Tokunaga I,Kubo S. Toluene inhalation-induced adrenocortical hypertrophy and endocrinological changes in rat.Life Sci. 2005; 76(17): 1929-37. 


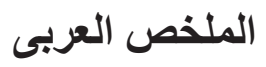

\title{
دراسة بيوكيميائية و تركيبية لتأثير التعرض لمادة التولوين على الجزء القاصى للغدة النخامية الامامية في الأكور الناضجة للفئر ان البيضاء
}

\author{
رشا ربيع سالم - ميلاد نعيم بشرى قلادة \\ قسم التثريح - كلية الطب - جامعة الإسكندرية
}

المقدمه: مادة التولوين مادة كيميائية ملوثة للبيئة وهى تستخدم على نطاق واسع كمذيب عضوى و ايضا لانتاج الكثير من المنتجات الصناعية. ان لها تأثثر ضار وسمى على الكثير من اعضاء الجسم مثل الكبد والكلى و الجهاز العصبى المركزى وتسبب خلل مناعى. ولها القدرة على التأثير على عملية تكون الميالين العصبى واختراق الحاجز الدموى المخى. القليل معروف عن تأثثر مادة التولوين على خلايا الغدة النخامية الامامية ولا توجد در اسات كافيةعن تأثير مادة التولوين على الثكل والتركيب الهستولوجى لخلايا الغدة النخامية. الهرف من البحث: تقييم تركيب الجزء القاصى بعد التعرض لمادة التولوين وربط التغيرات الكيميائية مع التغيرات الهستولوجية فى محاولة لمعرفة الألية الممكنة لهذه التغير ات. مواد وطرق البحث: تم اجر اء الدر اسة على عشرين من ذكور الفئران البيضاء الناضجة تم تقسيمها لمجمو عتين كالاتى: مجمو عة تحكم تتكون من عشرة فئر ان، مجموعة تعرض للتولوين تتكون من عشرة فئر ان تم تعريضها يوميا لابخرة

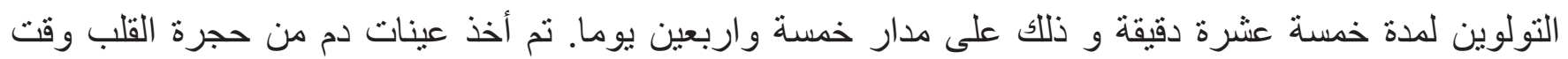
الوفاة لتقييم الهرمونات التالية: الهرمون المحفز للغدة الدرقية، الهرمون المحفز للحوصلة، الهرمون الملوتن، الهرمون المحفز للغدة الكظرية، هرمون النمو، هرمون البرو لاكتين. تم تشريح وفصل الفص الامامي للغدة النخامية لكل فأر وتم تقسيم كل عينة لجزئين: الجزء الاول تمت صباغته بالهيماتوكسيللين والايوسين. - الجزء الثانى تم تحضيره وفحصه

$$
\text { بالميكروسكوب الالكترونى. }
$$

النتائج: النتائج الكيميائية: فى مجموعة الفئران اللتى تعرضت للتولوين كان هنالك انخفاض ذو اهمية فى مستوى الهرمون المحفز للغدة الدرقية، الهرمون المحفز للحوصلة، الهرمون الملونن وهرمون النمو وكان هناك انخفاض غير ذو اهمية فى مستوى الهرمون المحفز للغدة الكظرية وهرمون البرو لاكتين. النتائج الميكروسكوبية: لقد اظهرت خلايا المجمو عة اللتى تعرضت لمادة التولوين فقدان للبنية الاساسية، سيتوبلازم ذو تجاويف، نو اة منكمشة غير منتظمة بنسبة كروماتين سميك مرتفعة و القليل من الحويصلات الافرازية. الاستنتاج: لقد حفز تعرض خلايا الجزء القاصى لمادة التولوين تغير ات تركيبية وشكلية فى معظم الخلايا وحفز ايضا تغيير ات فى الهرمونات المفرزة منها. 